\title{
Degradation in Solid Oxide Electrolysis Cells During Long Term Testing
}

\author{
Sun, X.; Hendriksen, P. V.; Mogensen, M. B.; Chen, M.
}

Published in:

Fuel Cells

Link to article, DOI:

10.1002/fuce.201900081

Publication date:

2019

Document Version

Peer reviewed version

Link back to DTU Orbit

Citation (APA):

Sun, X., Hendriksen, P. V., Mogensen, M. B., \& Chen, M. (2019). Degradation in Solid Oxide Electrolysis Cells During Long Term Testing. Fuel Cells, 19(6), 740-747. https://doi.org/10.1002/fuce.201900081

\section{General rights}

Copyright and moral rights for the publications made accessible in the public portal are retained by the authors and/or other copyright owners and it is a condition of accessing publications that users recognise and abide by the legal requirements associated with these rights.

- Users may download and print one copy of any publication from the public portal for the purpose of private study or research.

- You may not further distribute the material or use it for any profit-making activity or commercial gain

- You may freely distribute the URL identifying the publication in the public portal

If you believe that this document breaches copyright please contact us providing details, and we will remove access to the work immediately and investigate your claim. 


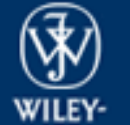

Fuel Cells

VCH

\section{Degradation in solid oxide electrolysis cells during long term testing}

\begin{tabular}{|r|l|}
\hline Journal: & Fuel Cells \\
\hline Manuscript ID & Draft \\
\hline Wiley - Manuscript type: & Original Research Paper \\
\hline Date Submitted by the & n/a \\
\hline Complete List of Authors: & $\begin{array}{l}\text { Sun, Xiufu; Danmarks Tekniske Universitet, Energy Conversion and } \\
\text { Storage } \\
\text { Hendriksen, Peter Vang; Danmarks Tekniske Universitet, Energy } \\
\text { Conversion and Storage } \\
\text { Mogensen, Mogens; Danmarks Tekniske Universitet, Energy Conversion } \\
\text { and Storage } \\
\text { Chen, Ming; Danmarks Tekniske Universitet, Energy conversion and } \\
\text { storage }\end{array}$ \\
\hline Keywords: & $\begin{array}{l}\text { Solid oxide cell, Electrolysis, Hydrogen production, Long term } \\
\text { performance, Ni migration }\end{array}$ \\
\hline &
\end{tabular}

\section{SCHOLARONE \\ Manuscripts}




\title{
Degradation in solid oxide electrolysis cells during long term testing
}

\author{
X. Sun*, P. V. Hendriksen, M. B. Mogensen, M. Chen ${ }^{+}$ \\ Department of Energy Conversion and Storage, Technical University of Denmark,Risø Campus, \\ Frederiksborgvej 399, DK-4000 Roskilde, Denmark
}

[*] Corresponding author: xisu@dtu.dk

$\left[^{+}\right]$Corresponding author: minc@dtu.dk 


\begin{abstract}
In this work, we report a 4,400 hours test of a state-of-the-art Ni-YSZ (yttria stabilized zirconia) electrode supported solid oxide electrolysis cell. The electrolysis test was carried out at $800{ }^{\circ} \mathrm{C},-1 \mathrm{~A} \mathrm{~cm}{ }^{-2}$ with $10 \% \mathrm{H}_{2}+90 \% \mathrm{H}_{2} \mathrm{O}$ supplied to Ni-YSZ electrode compartment. Except for the first 250 hours of fast initial degradation, the cell showed rather stable performance with a moderate degradation rate of around $25 \mathrm{mV}$ per 1,000 h. The electrochemical impedance spectra acquired during the test show that both serial resistance and electrode polarization resistance increased during the durability test. Further impedance analyses show that both the LSCF (strontium and cobalt co-doped lanthanum ferrite)-CGO (gadolinium doped ceria) electrode and Ni-YSZ electrode degraded and the degradation was dominated by the NiYSZ electrode. Post-mortem analysis on the Ni-YSZ electrode revealed loss of contact between Ni-Ni grains, Ni-YSZ grains and increased porosity inside the active layer. The microstructural changes were most severe at steam gas inlet and became less severe along the gas flow path. The present test results show that this type of cell can be used for early demonstration of solid oxide cell operation at electrolysis current densities around $1 \mathrm{~A} \mathrm{~cm}^{-2}$.
\end{abstract}

Key words: Solid oxide cell, Electrolysis, Hydrogen production, Long term performance, Ni migration 


\section{Introduction}

Solid oxide cells (SOC) for electrolysis application has attracted increasing interest recently due to its high power to gas efficiency and capability of co-electrolysis $\mathrm{H}_{2} \mathrm{O}$ and $\mathrm{CO}_{2}$ for syngas $\left(\mathrm{H}_{2}+\mathrm{CO}\right)$ production [1-6]. The excellent reversibility between solid oxide fuel cell (SOFC) mode for power generation and solid oxide electrolysis cell (SOEC) mode for fuel production makes SOC very attractive also for grid balance applications [7-11]. The demonstration of long-term durable operation is highly required for promoting the potential of SOC technology. A life time of 5 years with high fuel production rate is considered a requirement for a broad commercialization $[2,12]$. An SOEC is essentially the same cell as SOFC which is operated in reverse current direction and hence a cell that performs well as an SOFC is also likely to be a good cell for the reverse reaction. It has been reported that kinetics for $\mathrm{H}_{2}$ or $\mathrm{CO}$ oxidization are slightly faster than for $\mathrm{H}_{2} \mathrm{O}$ or $\mathrm{CO}_{2}$ reduction[13,14]. When comparing performance in fuel cell mode and electrolysis mode, an important difference is that heat evolution in the process. In SOFC mode the process is highly exothermic, while in SOEC mode it is dependent on the operation voltage whether heat is produced or consumed in the electrolysis overall process (considering both reaction entropy changes and joule heat). When operating the SOEC above thermo-neutral voltage (e.g. $1.29 \mathrm{~V}$ for steam electrolysis and $1.46 \mathrm{~V}$ for $\mathrm{CO}_{2}$ electrolysis), the process will be exothermal, and below thermo-neutral voltage it is endothermic. Extensive efforts have been devoted to studying the degradation of SOECs in recent years. Different degradation behaviors have been reported for different cell types (i.e. electrode and electrolyte materials) and different operation conditions (i.e. current density, gas composition etc.). It has been reported that impurities inside the fuel electrode gas feed stream is a main cause of degradation when operated at low current density (above $-1 \mathrm{~A} \mathrm{~cm}^{-2}$ ). Insignificant degradation was reported for over 500 hours of testing by cleaning the inlet gas stream supplied to the Ni-YSZ 
electrode compartment $[15,16]$. However, when operating the SOEC at high electrolysis current density (above $1 \mathrm{~A} \mathrm{~cm}^{-2}$ ) or correspondingly high over-potential, severe degradation has been widely reported [17-27]. At the Ni-YSZ electrode, beside loss of contact between $\mathrm{Ni}$ and $\mathrm{Ni}$ grain due to $\mathrm{Ni}$ agglomeration or $\mathrm{Ni}$ migration $[19,20,28]$, nano $\mathrm{ZrO}_{2}$ precipitation from $\mathrm{Zr}$ dissolved in the $\mathrm{Ni}$ bulk was observed [29,30]. The formation of small cavities inside YSZ grains and cracks along the grain boundary close to electrolyte - oxygen electrode interface has also been reported [18, 20]. The reason for this has been mainly attributed to the high oxygen activity build up inside the electrolyte close to the electrolyte-oxygen electrode interface at high over-potential $[19,31]$. The application of better performing oxygen electrodes based on strontium doped lanthanum cobaltite (LSC) or strontium and cobalt co-doped lanthanum ferrite (LSCF) helps to decrease the over-potential at high current density and thus prevents the formation of these cavities [22]. In a recent publication, a 9,000 hours steam electrolysis operation at $1 \mathrm{~A} \mathrm{~cm}^{-2}$ was reported by Schefold and co-authors [32]. The cell has a LSCF oxygen electrode and it showed a degradation rate of $40 \mathrm{mV} / 1,000$ hours when evaluated over the entire period. Composite electrode with CGO and LSCF have been reported to possess better electrochemical performance than pure LSCF electrode $[33,34]$. In the present work, we report on performance of a durable SOEC cell with LSCF-CGO oxygen electrode for steam electrolysis tested at $1 \mathrm{~A} \mathrm{~cm}^{-2}$ over 4,400 hours. Detailed DC and $\mathrm{AC}$ analysis were performed to elucidate the degradation behavior of the cell. Furthermore, post-test microstructure characterization was carried out to examine possible causes of the degradation.

\section{Experimental}

Planar solid oxide cells were used in this study. The cell consists of a fuel electrode with a thick Ni - 3 mol\% $\mathrm{Y}_{2} \mathrm{O}_{3}$ doped $\mathrm{ZrO}_{2}$ porous mechanical support ( $300 \mu \mathrm{m}$ in thickness) electrode and a Ni $-8 \mathrm{~mol} \%$ 
$\mathrm{Y}_{2} \mathrm{O}_{3}$ doped $\mathrm{ZrO}_{2}\left(\mathrm{Ni}\right.$-YSZ) active electrode $\left(10 \mu \mathrm{m}\right.$ in thickness) , a $\sim 12 \mu \mathrm{m}$ thick 8 mol\% $\mathrm{Y}_{2} \mathrm{O}_{3}$ stabilized $\mathrm{ZrO}_{2}$ (YSZ) electrolyte, a $\mathrm{Ce}_{0.9} \mathrm{Gd}_{0.1} \mathrm{O}_{1.95}$ (CGO) inter diffusion barrier layer (10 $\mu \mathrm{m}$ in thickness) made by screen printing and a $\mathrm{La}_{0.6} \mathrm{Sr}_{0.4} \mathrm{Co}_{0.2} \mathrm{Fe}_{0.8} \mathrm{O}_{3-\delta}$ (LSCF)-CGO composite oxygen electrode. The cell area is $5.3 \mathrm{~cm} \times 5.3 \mathrm{~cm}$ with an active electrode area of $4 \mathrm{~cm} \times 4 \mathrm{~cm}\left(16 \mathrm{~cm}^{2}\right)$. For testing, an alumina cell test house was used. Details on the cell test house is described elsewhere [15, 35]. The cell was sandwiched between gas distribution layers (corrugated Au and Ni meshes on the oxygen electrode and fuel electrode side, respectively), current collector layers (Au and Ni foils on the oxygen and the fuel electrode side, respectively), and the alumina cell test house. The cell was sealed at its edges by glass. At start up, the cell was heated up to $850{ }^{\circ} \mathrm{C}$ and the Ni-YSZ electrode was reduced in $\mathrm{H}_{2}+4 \%$ $\mathrm{H}_{2} \mathrm{O}$.

In this work two nominally identical cells were tested, one was used as a reference cell which was only exposed to initial performance characterization. The other one was exposed to initial and final performance characterizations before and after long-term durability test. The initial performance characterization on both cells was carried out by measuring DC polarization $(\mathrm{iV})$ curves and AC electrochemical impedance spectra (EIS) at 850,800 and $750{ }^{\circ} \mathrm{C}$. EIS characterizations were performed by varying the gas atmospheres at the Ni-YSZ electrode, i.e. by changing the $\mathrm{H}_{2} \mathrm{O}$ partial pressure in the $\mathrm{H}_{2}+\mathrm{H}_{2} \mathrm{O}$ mixture while keeping all the other parameters constant or at the LSCF-CGO electrode by switching between air and $\mathrm{O}_{2}$.

The durability test were performed under galvanostatic electrolysis conditions at $800{ }^{\circ} \mathrm{C}$ with a current density of $-1 \mathrm{~A} \mathrm{~cm}^{-2} \cdot 10 \% \mathrm{H}_{2}+90 \% \mathrm{H}_{2} \mathrm{O}$ was supplied to the fuel electrode compartment and pure oxygen was supplied to the oxygen electrode compartment in order to avoid any changes to the oxygen electrode composition with start of the electrolysis. The steam was produced by combusting $\mathrm{H}_{2}$ with $\mathrm{O}_{2}$ at the gas inlet to the Ni-YSZ electrode. The steam conversion calculated from the current using Farady's 
law was $56 \%$. In this study, the gasses supplied to the Ni-YSZ electrode were cleaned by passing through $8 \mathrm{~g}$ of the gas cleaning powder before entering the cell test house, following the procedure described by Ebbesen and Mogensen [36].

The impedance spectra were measured under zero DC current during initial performance characterization or under current during durability test using a Solartron 1255B frequency analyzer with an external shunt in series with the cell. The spectra were recorded from $96,850 \mathrm{~Hz}$ to $0.08 \mathrm{~Hz}$ with 12 points per decade and were corrected using the short circuit impedance response of the test setup. From the impedance spectra, the ohmic (serial) resistance $\left(\mathrm{R}_{\mathrm{s}}\right)$ was taken as the value of the real part of the impedance measured at $96,850 \mathrm{~Hz}$ and the polarization resistance $\left(\mathrm{R}_{\mathrm{p}}\right)$ was taken as the difference between the real part of the impedance at $96,850 \mathrm{~Hz}$ and $0.08 \mathrm{~Hz}$. The total area specific resistance of the cell was calculated as the total resistance of the real part $\left(\mathrm{R}_{\mathrm{s}}+\mathrm{R}_{\mathrm{p}}\right)$ of the impedance. To deconvolute the impedance into different contributions from individual cell components, the impedance spectra were fitted to equivalent circuits by complex-non-linear-least-square (CNLS) method using the RAVDAV software [37]. Distribution of relaxation times (DRT) was used for identifying the characteristic frequency response of the different electrochemical process prior to the CNLS fitting. The equivalent circuit model used for CNLS fit of the impedance spectra is given in Figure 1 where $\mathrm{L}$ is inductance, $\mathrm{R}$ is resistance, $\mathrm{Q}$ is a constant phase element and $\mathrm{G}$ represents a Gerisher element. The applied equivalent circuit consists of 7 impedance elements connected in series. The inductance, $\mathrm{L}$ originates from the test setup, an Ohmic resistor $\left(R_{s}\right)$ represents the Ohmic resistance of the cell. The high frequency process $R Q_{\text {comp }}$ with a summit frequency around $10 \mathrm{kHz}$ is tentatively ascribed to the resistance from the composite electrode mainly contributed by the Ni-YSZ electrode, and $\mathrm{RQ}_{\mathrm{Ni}-\mathrm{YSZ}_{-} \mathrm{TPB}}$ for charge transfer in the Ni-YSZ electrode with a summit frequency around $1 \mathrm{kHz}$, a Gerisher element $\mathrm{G}$ representing the oxygen surface exchange and oxide ion diffusion in the bulk of the oxygen electrode, and two RQ elements representing 
i) mass transport process by gas diffusion with main resistance contribution from the Ni-YSZ support, and ii) gas conversion polarization [38-40]. The combination of $R_{Q_{\text {comp }}}$ and $R Q_{N i-Y S Z}$ TPB together constitute the Ni-YSZ electrode polarization resistance $\mathrm{R}_{\mathrm{Ni}-\mathrm{YSZ}}$ and the combination of $\mathrm{RQ}_{\text {diffusion }}$ and $\mathrm{RQ}_{\text {conversion }}$ together accounts for the total gas concentration polarization resistance $\mathrm{R}_{\text {conc }}$.

The microstructure of the two cells was analyzed using a Supra 35 scanning electron microscope (SEM) equipped with a field emission gun (FE-SEM) and an energy-dispersive X-ray spectrometer (EDXS) from Thermo Electron Corporation. For each cell, a section from the middle area was vacuum embedded in Struers epoxy resin (Epofix), followed by grinding using SiC paper and polishing using 6, 3, and 1 and $0.5 \mu \mathrm{m}$ diamond paste. The cross-sections of the samples were examined using a Supra 35 with a state-of-the-art electron optic system configured for high resolution and high contrast specifically in low voltage applications. Two SEM modes were used: low voltage (LV) and backscattered electron (BSE) SEM. For applying the low voltage charge contrast technique, a sample without carbon coating, an accelerating voltage of $0.95 \mathrm{kV}$ and an Inlens detector were used. The obtained image under such conditions provides information on $\mathrm{Ni}$ in the Ni-YSZ electrode. Ni grains in the LV image appear either light or dark, depending on whether they are in electric contact with or not a part of the Ni network, respectively [41]. For the BSE mode, an accelerating voltage of $15 \mathrm{kV}$ was used. These samples were carbon coated to eliminate surface charging.

\section{Results}

\subsection{Cell voltage degradation}


Figure 2 shows the time evolution of the cell voltage during the galvanostatic test at $-1 \mathrm{~A} \mathrm{~cm}^{-2}$ with $10 \%$ $\mathrm{H}_{2}+90 \% \mathrm{H}_{2} \mathrm{O}$ supplied to the fuel electrode at a flow rate corresponding to $56 \%$ steam utilization. The theoretical outlet gas composition from the Ni-YSZ electrode was $60 \% \mathrm{H}_{2}+40 \% \mathrm{H}_{2} \mathrm{O}$ and the $\mathrm{H}_{2}$ production rate was $4.8 \mathrm{Nm}^{3} \mathrm{~m}^{-2} \mathrm{~h}^{-1}$. Figure 2 also displays the "instantaneous" degradation rate. Relatively high degradation rate was observed during the first 200 hours, where the cell voltage increased from $1.16 \mathrm{~V}$ to $1.3 \mathrm{~V}$ with a degradation rate of around $600 \mathrm{mV}$ per $1,000 \mathrm{~h}(52 \%$ of initial cell voltage per $1,000 \mathrm{~h})$. After the fast initial degradation, the cell started to re-activate and showed stable performance in the period from 250 to 1,100 hours without degradation. The overall cell voltage degradation in the entire experiment was $4.6 \%$ of initial cell voltage per $1,000 \mathrm{~h}(53 \mathrm{mV}$ per $1,000 \mathrm{~h})$, whereas the long term degradation rate evaluated from 1,100 hour till the end of the test is $1.9 \%$ of the voltage at 1,100 hour per 1,000 h (25 mV per 1,000 h).

\subsection{Electrochemical impedance analysis}

Electrochemical impedance spectra were recorded during the galvanostatic test at $-1 \mathrm{~A} \mathrm{~cm}^{-2}$ and the $R_{\mathrm{s}}$, $R_{\mathrm{p}}$, and $A S R$ were extracted from the impedance data. Figure 3 shows the Nyquist plot of the impedance spectra (Figure 3a) and the $R_{s}, R_{p}$ as well as ASR evolution with test time (Figure $3 b$ ). Both the serial resistance $\left(R_{s}\right)$ and polarization resistance $\left(R_{p}\right)$ increased during the durability test. The average $R_{s}, R_{p}$ and ASR degradation rate over the entire galvanostatic test are 10,72 and $82 \mathrm{~m} \Omega \mathrm{cm}^{2}$ per $1,000 \mathrm{~h}$, respectively. The $R_{p}$ showed high degradation rate of $1.2 \Omega \mathrm{cm}^{2}$ per $1,000 \mathrm{~h}$ in the first 200 hours, followed by an activation / stabilization period from 200 hours to 1,100 hours with a degradation rate around $-22 \mathrm{~m} \Omega \mathrm{cm}^{2}$ per $1,000 \mathrm{~h}$ and afterwards increased to $20 \mathrm{~m} \Omega \mathrm{cm}^{2}$ per $1,000 \mathrm{~h}$ for the rest of the test period. The $\mathrm{R}_{\mathrm{s}}$ showed rather liner degradation during the entire electrolysis test period. 
The distribution of relaxation times (DRT) method was applied to further analyze the degradation behavior of the cell. The DRT method allows distinguishing the physiochemical process that give rise to the overall impedance of a cell, provided that these processes have different characteristic time constants. Five electrochemical processes have been reported on cells similar to the ones used in the present study[40,42]. Two high frequency peaks with summit frequencies at around $10 \mathrm{kHz}$ and $7-10 \mathrm{kHz}$ at 800 ${ }^{\circ} \mathrm{C}$ can be attributed to the oxide ion transport and charge transfer processes with the main resistance contributions from the Ni-YSZ electrode. The middle frequency peak at around 100-200 Hz can be attributed to the oxygen surface exchange and $\mathrm{O}^{2-}$ transport inside the LSCF-CGO electrode. The two low frequency peaks with summit frequencies at 20-50 Hz and 1-10 Hz are due to gas diffusion and gas conversion process, respectively. Figure 4 plots the DRT result of the electrochemical impedance spectra recorded during the galvanostatic test. Five distinguishable peaks can be seen from Figure 4 . All the process show increasing resistance during the durability test. A strong shift of the summit frequency from $5 \mathrm{kHz}$ to $800 \mathrm{~Hz}$ was observed on the Ni-YSZ TPB process, and the DRT peak showed fast increase over the first 200 hours and afterwards activation (i.e. resistance decrease) until around 1,100 hours. A change in the gas concentration peak is also observed in Figure 4 in the frequency range of 1-10 Hz.

To further break down the impedance in contributions from individual cell components or processes, the impedance spectra were fitted with the equivalent circuit model described in Figure 1 using the complex nonlinear least squares fitting (CNLS) method. Figure 5 plots the evolution of the polarization resistance of the different elements as a function of test time. The initial values of $R_{s}, R_{N i-Y S Z}$ and $R_{\text {conc }}$ are very close, while the polarization resistance of the LSCF-CGO electrode $\mathrm{R}_{\mathrm{LSCF}-\mathrm{CGO}}$ is about half of that of the Ni-YSZ electrode $\mathrm{R}_{\mathrm{Ni}-\mathrm{YSZ}}$. During the durability test, the polarization resistance of all the processes 
increased. The $\mathrm{R}_{\mathrm{Ni}-\mathrm{YSZ}}$ and $\mathrm{R}_{\text {conc }}$ increased very fast over the first 200 hours with degradation rates of 0.8 $\Omega \mathrm{cm}^{2}$ per $1,000 \mathrm{~h}$ and $0.4 \Omega \mathrm{cm}^{2}$ per $1,000 \mathrm{~h}$, respectively. The degradation of the LSCF-CGO electrode lasted around $400 \mathrm{~h}$ with a degradation rate of $0.07 \Omega \mathrm{cm}^{2}$ per $1,000 \mathrm{~h}$ and remained relatively stable afterwards. The serial resistance $\mathrm{R}_{\mathrm{s}}$ shows steady degradation (ca. $10.5 \mathrm{~m} \Omega \mathrm{cm}^{2}$ per $1,000 \mathrm{~h}$ ) during the entire electrolysis test period.

\subsection{Performance comparison before and after the durability test}

Figure 6 shows the iV curves and impedance spectra measured with $10 \% \mathrm{H}_{2}+90 \% \mathrm{H}_{2} \mathrm{O}$ supplied to the Ni-YSZ electrode compartment and $\mathrm{O}_{2}$ supplied to the LSCF-CGO electrode compartment before and after the durability test. The impedance spectra were taken at $0 \mathrm{~A}$ DC current (OCV) and were fitted using the equivalent circuit model presented in Figure 1. As seen from the iV curves, OCV remains unaltered after the durability test, which shows that gas tightness of the cell and test setup over the entire 6-month test period did not change. On the other hand, the iV performance after the durability test was clearly inferior to the one measured before. The cell voltage at $-1 \mathrm{~A} \mathrm{~cm}^{-2}$ was $1,155 \mathrm{mV}$ before the durability test and $1,386 \mathrm{mV}$ after the durability test, which translates to an average degradation rate of $53 \mathrm{mV}$ per $1,000 \mathrm{~h}$ or $4.6 \%$ per $1,000 \mathrm{~h}$. The impedance spectra show an initial ASR of $0.328 \Omega \mathrm{cm}^{2}$, which increased to $0.458 \Omega \mathrm{cm}^{2}$ after the durability test. This corresponds to an average ASR degradation rate of $29.7 \mathrm{~m} \Omega \mathrm{cm}^{-2}$ per $1,000 \mathrm{~h}$ over the entire test period. The EIS also shows that both Rs and Rp increased during the durability test. The breakdown of different electrochemical process contributions to the cell resistance of the EIS measured under 0 and $-1 \mathrm{~A} \mathrm{~cm}^{-2}$ before and after the durability test is presented in Table 1. A relatively small contribution from the LSCF-CGO electrode can be seen, even 
though the polarization resistance is more or less doubled for the LSCF-CGO electrode after the durability test. Strong degradation of the Ni-YSZ electrode polarization is evident, it has increased around 2.5 times over the entire durability test. The serial resistance increased around 1.5 times over the durability test. Furthermore, increase of gas concentration polarization is also observed especially under $-1 \mathrm{~A} \mathrm{~cm}^{-2}$.

\subsection{Microstructure characterization}

Figure 7 presents the LV and BSE images of the Ni-YSZ electrode at the inlet and outlet of the durability tested cell as well as the reference cell. A significant loss of $\mathrm{Ni}$ - Ni electric contact in the active Ni-YSZ electrode was found in the tested cell. The degree of Ni loss was found to be most pronounced at the inlet and with decreasing degree of loss of Ni interconnection along the hydrogen-steam flow path. At the inlet of the tested cell, the BSE image (Figure 7a) further reveals an increase of porosity for the active electrode layer (within $10 \mu \mathrm{m}$ from the electrolyte-electrode interface) and a decrease of porosity in the neighboring support layer (within 10-20 $\mu \mathrm{m}$ from the electrolyte-electrode interface). The porosity change becomes less and less along the hydrogen-steam flow path. The porosity change seems to be a consequence of $\mathrm{Ni}$ redistribution, Ni migration from the active electrode layer towards the neighboring support layer, as evidenced by the EDS line scan results shown in Figure 8. An area covering both the active electrode and the neighboring support (similar to the ones shown in Figure 7) was selected for EDS spectral imaging. Based on the collected EDS spectra, an integrated EDS line scan was then made perpendicular to the electrolyte-electrode interface and the derived $\mathrm{Ni} /(\mathrm{Y}+\mathrm{Zr})$ ratio is illustrated in Figure 8. 
For the oxygen side, in comparison with the reference cell, the tested cell shows almost no microstructure change except for a small region at the inlet (1 $\mathrm{mm}$ in length along the hydrogen-steam flow path). As shown in Figure 9a, in the area highlighted with white oval, a change of the morphology in the upper part of the CGO layer was observed. In addition, the neighboring LSCF-CGO oxygen electrode has become more porous. For the other part of the tested cell, the microstructure of the oxygen side (Figure $9 b$ ) is similar to that of the reference cell (Figure 9c). No significant change of the Sr concentration in the CGO barrier layer was observed from EDS in the tested cell as compared with the reference cell. The difference in the thickness of the CGO barrier layer between the tested cell and the reference cell is due to variation in the cell production process.

\section{Discussion}

Both the serial and the polarization resistance increased during the cell test (Figure 6). Further, the CNLS fitting results revealed that both the Ni-YSZ electrode and LSCF-CGO electrode degraded during the durability test. The results are in agreement with the DRT analysis of the impedance spectra measured during the durability test (Figure 4). During the durability test, the Ni-YSZ electrode resistance increased around 2.6 times and the LSCF-CGO electrode resistance increased around 1.8 times. It is worth noting that the resistance contribution from the oxygen electrode polarization is much smaller than that of $\mathrm{Ni}$ YSZ.

During the electrolysis test, the cell voltage showed a fast increase rate in the first 250 hours, which accounts for $62 \%$ of the total degradation. DRT analysis and CNLS fitting of the impedance spectra 
measured during the durability test reveals that the fast degradation is mainly due to the increase in the polarization resistance of the TPB process in the Ni-YSZ electrode and of the concentration polarization. Even though the polarization resistance of the LSCF-CGO electrode increased as well, its contribution is rather small. The fast initial Ni-YSZ electrode degradation has been previously reported on similar Ni-YSZ supported cells with LSM-YSZ oxygen electrode and similar Ni-YSZ structures for both $\mathrm{H}_{2} \mathrm{O}$ electrolysis [19] and $\mathrm{H}_{2} \mathrm{O}+\mathrm{CO}_{2}$ co-electrolysis [18], which indicates that this kind of degradation phenomenon may have a weak dependency on electrolysis current density, Ni-YSZ electrode compartment gas composition, and oxygen electrode materials. The cause of this fast increase of Ni-YSZ TPB resistance is most likely due to the loss of active TPB sites, resulted from loss of Ni-Ni or Ni-YSZ contact [43]. The activation period after the initial fast degradation might be due to (to a small extent) some sort of re-establishment of Ni-Ni contact and hence some more active TPB sites achieved by Niparticle growth.

Even though the gas fed to the Ni-YSZ electrode was cleaned before it enters the cell test house, impurity poisoning of the Ni-YSZ electrode could still be one of the reasons for the initial Ni-YSZ degradation as impurities may also come from sealing material and from raw materials of cell components. The cause of increase in the concentration polarization resistance during the electrolysis durability study might be due to the uneven degradation of the Ni-YSZ electrode that partly deactivated the Ni-YSZ electrode and resulted in gas bypass along the $\mathrm{H}_{2}+\mathrm{H}_{2} \mathrm{O}$ flow path [20]. Meanwhile, the changing of microstructure/porosity at the Ni-YSZ electrode as seen in Figure 6 could also result in the changing of gas diffusion and thus gas concentration polarization resistance [44].

The electrochemical analysis showing that the observed resistance increase is associated with degradation at the Ni-YSZ electrode is well in line with the SEM observations. The loss of Ni percolation 
will of course result in loss of active TPB area and thus the increases of $\mathrm{RQ}_{\mathrm{Ni} \text {-YSZ_TPB. Under the }}$ galvanostatic test mode, depending on the degree of Ni percolation loss, the effective TPB extends from the active Ni-YSZ electrode - YSZ electrolyte interface into the active Ni-YSZ electrode. Besides the increasing of $\mathrm{RQ}_{\mathrm{Ni}-\mathrm{YSZ} \text {-TPB }}$, the $\mathrm{RQ}_{\text {comp }}$ should also increase due to increased distance of oxygen ion transportation in the active composite electrode. The degradation at the Ni-YSZ electrode is uneven varying from gas stream inlet to outlet as well as from active electrode to electrode support (Figure 7). At the inlet of the tested cell, enrichment of $\mathrm{Ni}$ in the support layer just next to the active electrode is clearly visible, while at the outlet of the tested cell and in the reference cell, the Ni distribution is rather homogeneous. In our previous studies, we have reported Ni-YSZ interfacial reactions and formation of $\mathrm{ZrO}_{2}$ nano-particles on Ni surface in cells exposed to high current density electrolysis operation [29]. Such phenomenon was however not found in the present test as confirmed by high resolution BSE images (not shown here). It can be concluded that for the present test the $\mathrm{Ni}$ percolation loss in the active electrode was caused mainly by redistribution of Ni from the active electrode to the neighboring support. It has been hypothesized in the literature that Ni migration and Ni particle coarsening are due to formation of $\mathrm{Ni}(\mathrm{OH})_{\mathrm{x}}$ gas species and its gradient inside the electrode which is highly dependent on the operating conditions such as temperature and steam content and polarization [45-47]. The $P_{\mathrm{Ni}(\mathrm{OH})_{x}}$ increases with the $P_{\mathrm{H}_{2} \mathrm{O}}$ and it is expected that $P_{\mathrm{H}_{2} \mathrm{O}}$ and $P_{\mathrm{Ni}(\mathrm{OH})_{x}}$ nearby the electrochemical active site where $\mathrm{H}_{2} \mathrm{O}$ is converted to $\mathrm{H}_{2}$ are lower than in the electrode support. In this work, a cross flow cell test setup was used. Along the $\mathrm{H}_{2}+\mathrm{H}_{2} \mathrm{O}$ flow direction, the steam partial pressure decreases and accordingly the Nernst potential increases. An uneven distribution of local current density follows with higher local current density (higher over-potential) at the inlet than at the outlet. This may accelerate cell degradation at the gas inlet of the cell, and may therefore partly account for the observed microstructure changes in the $\mathrm{Ni}$ - 
YSZ electrode along the $\mathrm{H}_{2}+\mathrm{H}_{2} \mathrm{O}$ flow direction. The migration of Ni from the Ni-YSZ electrode support layer and precipitated at electrode-electrolyte TPB interface has been report by Hauch et al [45], where such phenomenon was explained due to $P_{\mathrm{Ni}(\mathrm{OH})_{x}}$ gradient, as lower $P_{\mathrm{Ni}(\mathrm{OH})_{x}}$ is expected at the active TPB interface where $\mathrm{H}_{2} \mathrm{O}$ is converted to $\mathrm{H}_{2}$ under electrolysis current. However in this work, the postmortem SEM showed an opposite direction of $\mathrm{Ni}$ migration. As aforementioned, under the galvanostatic test mode, depending on the degree of Ni percolation loss, the effective TPB area extends from the active Ni-YSZ electrode - YSZ electrolyte interface into the active Ni-YSZ electrode, or maybe even to the electrode support. It is speculated that at the inlet of the cell as shown in Figure $7 \mathrm{a}$, the electrochemical active site for $\mathrm{H}_{2} \mathrm{O}$ reduction moved from close to the active electrode - electrolyte interface to the active electrode-support interface during the electrolysis test. Thus the lowest $P_{\mathrm{Ni}(\mathrm{OH})_{x}}$ area also moved towards the electrode-support electrode area, as a result, the $\mathrm{Ni}(\mathrm{OH})_{\mathrm{x}}$ migrated from nearby high $P_{\mathrm{Ni}(\mathrm{OH})_{x}}$ area and reduced at the active site there and caused the decreases of the porosity in the area. A more detailed discussion on the Ni migration can be found in ref. 30 .

It has been reported in some studies of SOEC cell degradation that the main contribution is the serial resistance increase $[18,19,42]$. However, in this study the $R_{s}$ degradation rate is only $10 \mathrm{~m} \Omega \mathrm{cm}^{2}$ per 1,000h, which means that the $\mathrm{R}_{\mathrm{s}}$ will increase $0.4 \Omega \mathrm{cm}^{2}$ for a 40,000 hours test. On the other hand, for the longer term degradation (after 250 hours) the polarization resistance showed twice as high degradation as that of $R_{s}$, showing that the polarization resistance degradation (mainly the Ni-YSZ TPB process) dominated the long-term cell degradation. The large serial resistance degradation has in several studies been ascribed to the formation of crack inside the electrolyte or the delamination between the oxygen electrode and the electrolyte $[18,21,22,27]$. However, such crack or delamination was not seen in the present test. This may due to the fast oxygen exchange rate of the LSCF-CGO oxygen electrode, 
which reduces the possible oxygen pressure build-up close to the oxygen electrode-electrolyte interface[48]. The serial resistance, Rs increases in this study is most likely associated with the increased effective thickness of the ionic path as the active sites moves away from the electrolyte and into the composite fuel electrode and the decreased "effective" YSZ area available when the TPB reduces with time.

\section{Conclusion}

The 4,400 hours electrolysis test of the state-of-the-art Ni-YSZ electrode supported SOEC cell at $800{ }^{\circ} \mathrm{C}$, with a LSCF-CGO composite oxygen electrode operated under $-1 \mathrm{~A} \mathrm{~cm}^{-2}$ overall shows three degradation stages. According to the impedance analysis, the fast initial degradation occurring during the first 250 hours and the partial activation/stabilization from $250-1,100$ hours is mainly due to changes of the impedance of the Ni-YSZ TPB process. For the rest of the test period $(250-4,400 \mathrm{~h})$, the cell demonstrated fairly stable performance with a degradation rate of $25 \mathrm{mV}$ per 1,000 hours. The comparison of the initial and final performance shows that all the electrochemical processes of the cell degraded. The main contribution comes from the Ni-YSZ TPB process. Post-mortem analysis on the NiYSZ electrode revealed loss of percolation between $\mathrm{Ni}-\mathrm{Ni}$ grains and increased porosity inside the active Ni-YSZ electrode. The degree of these microstructural changes decreases along the hydrogen-steam flow path. Morphological change in the part of the CGO diffusion barrier and the LSCF-CGO electrode was observed at the cell location close to the hydrogen-steam inlet where current densities are highest and thus the oxygen electrode most polarized, while the oxygen electrode at the rest of location remained 
unchanged. The present test results show that this type of cell can be used for early demonstration electrolysis at $1 \mathrm{~A} \mathrm{~cm}^{-2}$.

\section{Acknowledgement}

The project ForskEL 2013-1-12013 "Solid Oxide Electrolysis for Grid Balancing" funded by Energinet.dk is gratefully acknowledged.

\section{References}

[1] W. Doenitz, R. Schmidberger, E. Steinheil, R. Streicher, Int. J. Hydrog. Energy 1980, 5, 55.

[2] S. H. Jensen, P. H. Larsen, M. Mogensen, Int. J. Hydrog. Energy 2007, 32, 3253.

[3] S. D. Ebbesen, C. Graves, M. Mogensen, Int. J. Green Energy 2009, 6, 646.

[4] J. E. O'Brien, C. M. Stoots, J. S. Herring, P. A. Lessing, J. J. Hartvigsen, S. Elangovan, J. Fuel Cell Sci. Technol. 2005, 2, 156.

[5] G. Schiller, A. Ansar, M. Lang, O. Patz, J. Appl. Electrochem. 2008, 39, 293.

[6] C. M. Stoots, J. E. O’Brien, J. S. Herring, J. J. Hartvigsen, J. Fuel Cell Sci. Technol. 2009, 6, 011014.

[7] S. H. Jensen, C. Graves, M. Mogensen, C. Wendel, R. Braun, G. Hughes, Z. Gao, S. A. Barnett, Energy Environ. Sci. 2015, 8, 2471.

[8] M. Ni, M. Leung, D. Leung, Int. J. Hydrog. Energy 2007, 32, 4648.

[9] E. Erdle, W. Dönitz, R. Schamm, A. Koch, Int. J. Hydrog. Energy 1992, 17, 817. 
[10] V. N. Nguyen, Q. Fang, U. Packbier, L. Blum, Int. J. Hydrog. Energy 2013, 38, 4281.

[11] D. M. Bierschenk, J. R. Wilson, S. A. Barnett, Energy Environ. Sci. 2011, 4, 944.

[12] Q. Fu, C. Mabilat, M. Zahid, A. Brisse, L. Gautier, Energy Environ. Sci. 2010, 3, 1382.

[13] S. D. Ebbesen, M. Mogensen, ECS Trans. 2013, 50, 167.

[14] J.-C. Njodzefon, D. Klotz, A. Kromp, A. Weber, E. Ivers-Tiffée, J. Electrochem. Soc. 2013, 160, F313.

[15] S. D. Ebbesen, C. Graves, A. Hauch, S. H. Jensen, M. Mogensen, J. Electrochem. Soc. 2010, 157, B1419.

[16] S. D. Ebbesen, M. Mogensen, Electrochem. Solid-State Lett. 2010, 13, B106.

[17] J. Kim, H.-I. Ji, H. P. Dasari, D. Shin, H. Song, J.-H. Lee, B.-K. Kim, H.-J. Je, H.-W. Lee, K. J. Yoon, Int. J. Hydrog. Energy 2013, 38, 1225.

[18] X. Sun, M. Chen, Y.-L. Liu, P. Hjalmarsson, S. D. Ebbesen, S. H. Jensen, M. B. Mogensen, P. V. Hendriksen, J. Electrochem. Soc. 2013, 160, F1074.

[19] R. Knibbe, M. L. Traulsen, A. Hauch, S. D. Ebbesen, M. Mogensen, J. Electrochem. Soc. 2010, 157, B1209.

[20] X. Sun, M. Chen, Y.-L. Liu, P. V. Hendriksen, M. Mogensen, ECS Trans. 2013, 57, 3229.

[21] F. Tietz, D. Sebold, A. Brisse, J. Schefold, J. Power Sources 2013, 223, 129.

[22] P. Hjalmarsson, X. Sun, Y.-L. Liu, M. Chen, J. Power Sources 2013, 223, 349.

[23] C. Graves, S. D. Ebbesen, M. Mogensen, Solid State Ion. 2011, 192, 398.

[24] S.-D. Kim, D.-W. Seo, A. K. Dorai, S.-K. Woo, Int. J. Hydrog. Energy 2013, 38, 6569.

[25] G. A. Hughes, K. Yakal-Kremski, S. A. Barnett, Phys. Chem. Chem. Phys. 2013, 15, 17257.

[26] M. Keane, M. K. Mahapatra, A. Verma, P. Singh, Int. J. Hydrog. Energy 2012, 37, 16776.

[27] K. Chen, S. P. Jiang, Int. J. Hydrog. Energy 2011, 36, 10541. 
[28] M. Hubert, J. Laurencin, P. Cloetens, B. Morel, D. Montinaro, F. Lefebvre-Joud, J. Power Sources 2018, 397, 240.

[29] M. Chen, Y.-L. Liu, J. J. Bentzen, W. Zhang, X. Sun, A. Hauch, Y. Tao, J. R. Bowen, P. V. Hendriksen, J. Electrochem. Soc. 2013, 160, F883.

[30] M. B. Mogensen, A. Hauch, X. Sun, M. Chen, Y. Tao, S. D. Ebbesen, K. V. Hansen, P. V. Hendriksen, Fuel Cells 2017, 17, 434.

[31] A. V. Virkar, Int. J. Hydrog. Energy 2010, 35, 9527.

[32] J. Schefold, A. Brisse, F. Tietz, J. Electrochem. Soc. 2011, 159, A137.

[33] E. Perry Murray, M. J. Sever, S. A. Barnett, Solid State Ion. 2002, 148, 27.

[34] V. Dusastre, J. A. Kilner, Solid State Ion. 1999, 126, 163.

[35] S. H. Jensen, A. Hauch, P. V. Hendriksen, M. Mogensen, J. Electrochem. Soc. 2009, 156, B757.

[36] S. D. Ebbesen, M. Mogensen, Method and System for Purification of Gas Streams for Solid Oxide Cells, 2011, EP2362475A1.

[37] C. Graves, RAVDAV Data Analysis Software, 2012.

[38] R. Barfod, A. Hagen, S. Ramousse, P. V. Hendriksen, M. Mogensen, Fuel Cells 2006, 6, 141.

[39] S. Primdahl, M. Mogensen, J. Electrochem. Soc. 1999, 146, 2827.

[40] A. Leonide, V. Sonn, A. Weber, E. Ivers-Tiffée, J. Electrochem. Soc. 2008, 155, B36.

[41] K. Thyden, Solid State Ion. 2008, 178, 1984.

[42] P. Hjalmarsson, X. Sun, Y.-L. Liu, M. Chen, J. Power Sources 2014, 262, 316.

[43] A. Hauch, M. Mogensen, A. Hagen, Solid State Ion. 2011, 192, 547.

[44] S. D. Ebbesen, X. Sun, M. B. Mogensen, Faraday Discuss. 2015, 182, 393.

[45] A. Hauch, S. D. Ebbesen, S. H. Jensen, M. Mogensen, J. Electrochem. Soc. 2008, 155, B1184.

[46] H. Yokokawa, H. Tu, B. Iwanschitz, A. Mai, J. Power Sources 2008, 182, 400. 
[47] A. Hagen, R. Barfod, P. V. Hendriksen, Y.-L. Liu, S. Ramousse, J. Electrochem. Soc. 2006, 153, A1165.

[48] K. Chen, S. P. Jiang, J. Electrochem. Soc. 2016, 163, F3070. 


\section{Figure Captions}

Figure 1: Equivalent circuit model used for impedance spectra CNLS fitting.

Figure 2: Time evolution of the cell voltage and degradation rate during electrolysis operation at $-1 \mathrm{~A}$ $\mathrm{cm}^{-2}$

Figure 3: Electrochemical impedance spectra measured during the electrolysis durability test (a) and extracted $R_{s}, R_{p}$ and ASR (b) evolution with test time at $-1 \mathrm{~A} \mathrm{~cm}^{-2}$.

Figure 4: DRT analysis of the impedance spectra recorded during the durability test at $-1 \mathrm{~A} \mathrm{~cm}^{-2}$.

Figure 5: Cell component/process resistances as a function of time based on break down of the impedance spectra measured during the durability test.

Figure 6: Cell performance characterizations before and after the durability test at $800{ }^{\circ} \mathrm{C}$ with $10 \% \mathrm{H}_{2}$ $+90 \% \mathrm{H}_{2} \mathrm{O}$ applied to the Ni-YSZ electrode and $\mathrm{O}_{2}$ applied to the LSCF-CGO electrode. a: iV curves, b: electrochemical impedance spectra measured under zero DC current.

Figure 7: BSE (left) and LV (right) images of the Ni-YSZ hydrogen electrode at the hydrogen-steam inlet (a) and outlet (b) for the long-term tested cell and inlet (c) and outlet (d) for the reference cell.

Figure 8: Atomic ratio of $\mathrm{Ni} /(\mathrm{Y}+\mathrm{Zr})$ for the active $\mathrm{Ni}-\mathrm{YSZ}$ hydrogen electrode and the support, derived from integrated EDS line scan perpendicular to the YSZ electrolyte - Ni-YSZ electrode interface.

Figure 9: BSE images (left) and EDS line-scan (right) of the LSCF-CGO oxygen electrode, CGO barrier layer and YSZ electrolyte at the hydrogen-steam inlet (a) and center (b) of the tested cell and the inlet (c) of the reference cell. 


\section{Table Captions}

Table 1: CNLS fit results of the impedance spectra at OCV and $-1 \mathrm{~A} \mathrm{~cm}^{-2}$ before and after the durability test

\section{Table}

\begin{tabular}{|l|l|l|l|l|l|l|l|l|}
\hline Resistance $/ \Omega \mathrm{cm}^{2}$ & \multicolumn{2}{l|}{$\mathrm{R}_{\mathrm{s}}$} & \multicolumn{2}{l|}{$\mathrm{R}_{\mathrm{Ni}-\mathrm{YSZ}}$} & \multicolumn{2}{l|}{$\mathrm{R}_{\mathrm{LSCF}-\mathrm{CGO}}$} & \multicolumn{2}{l|}{$\mathrm{R}_{\text {conc }}$} \\
\cline { 2 - 9 } & $\mathrm{OCV}$ & $-1 \mathrm{~A} \mathrm{~cm}^{-2}$ & $\mathrm{OCV}$ & $-1 \mathrm{~A} \mathrm{~cm}^{-2}$ & $\mathrm{OCV}$ & $-1 \mathrm{~A} \mathrm{~cm}^{-2}$ & $\mathrm{OCV}$ & $-1 \mathrm{~A} \mathrm{~cm}^{-2}$ \\
\hline Before test & 0.096 & 0.095 & 0.041 & 0.091 & 0.022 & 0.023 & 0.17 & 0.095 \\
\hline After test & 0.14 & 0.13 & 0.106 & 0.33 & 0.04 & 0.036 & 0.174 & 0.183 \\
\hline
\end{tabular}




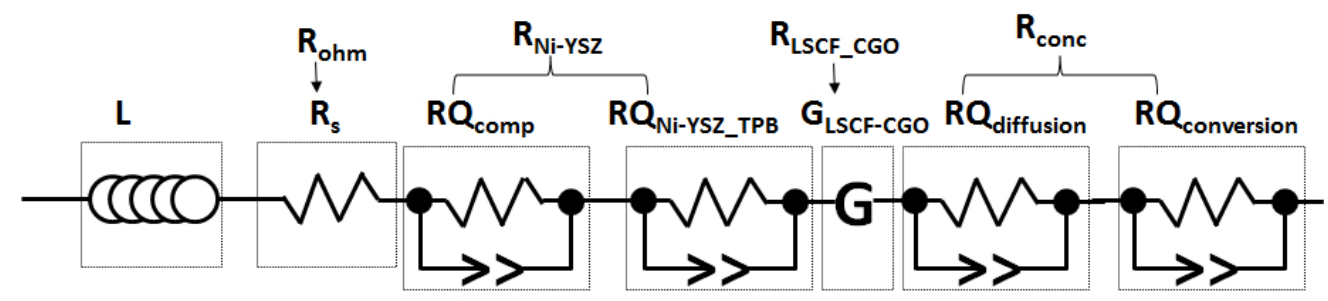

Figure 1 Equivalent circuit model used for impedance spectra CNLS fitting.

$77 \times 21 \mathrm{~mm}(300 \times 300 \mathrm{DPI})$ 


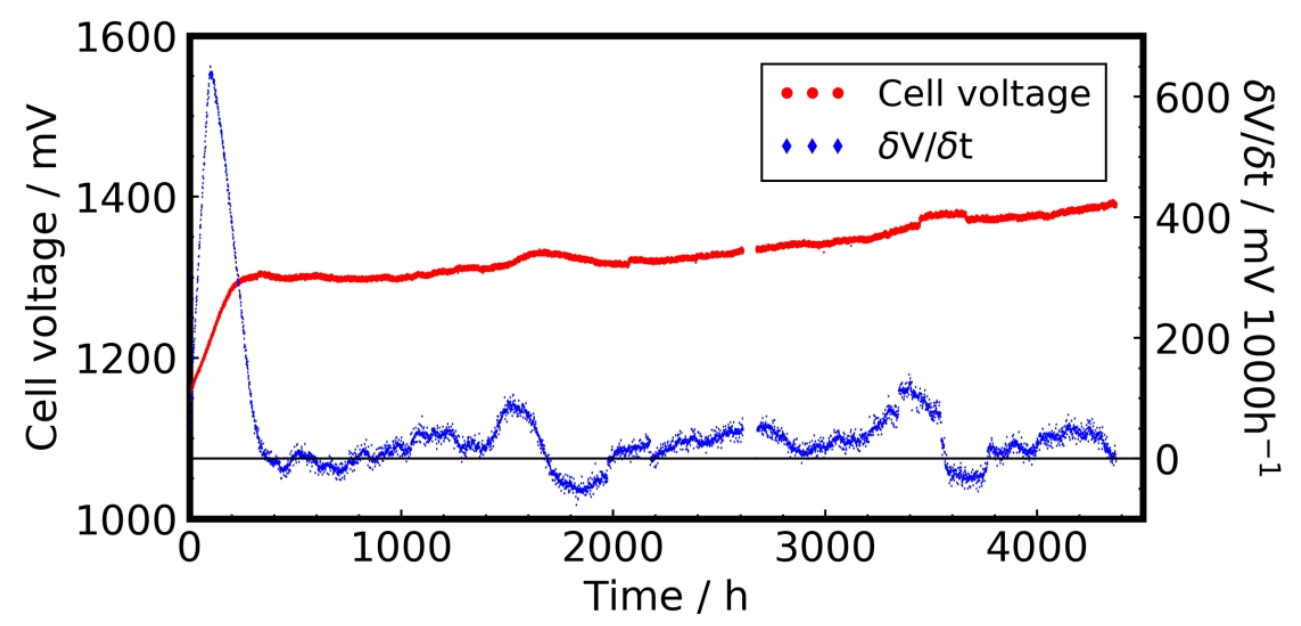

Figure 2: Time evolution of the cell voltage and degradation rate during electrolysis operation at $-1 \mathrm{Acm}^{-2}$. $203 \times 101 \mathrm{~mm}(300 \times 300$ DPI $)$ 

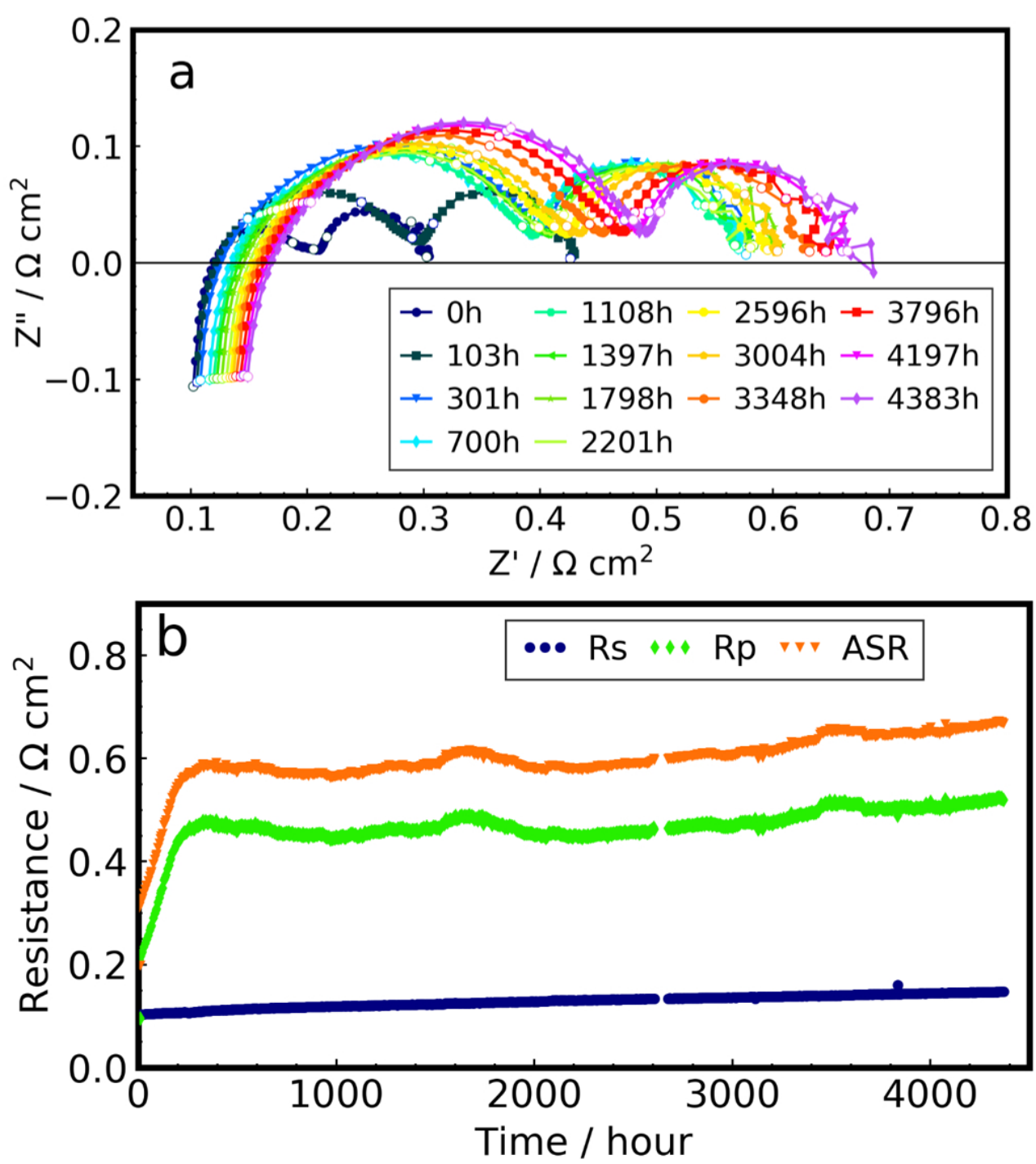

Figure 3: Electrochemical impedance spectra measured during the electrolysis durability test (a) and extracted Rs, Rp and ASR (b) evolution with test time at $-1 \mathrm{~A} \mathrm{~cm}^{-2}$.

$88 \times 98 \mathrm{~mm}(300 \times 300 \mathrm{DPI})$ 


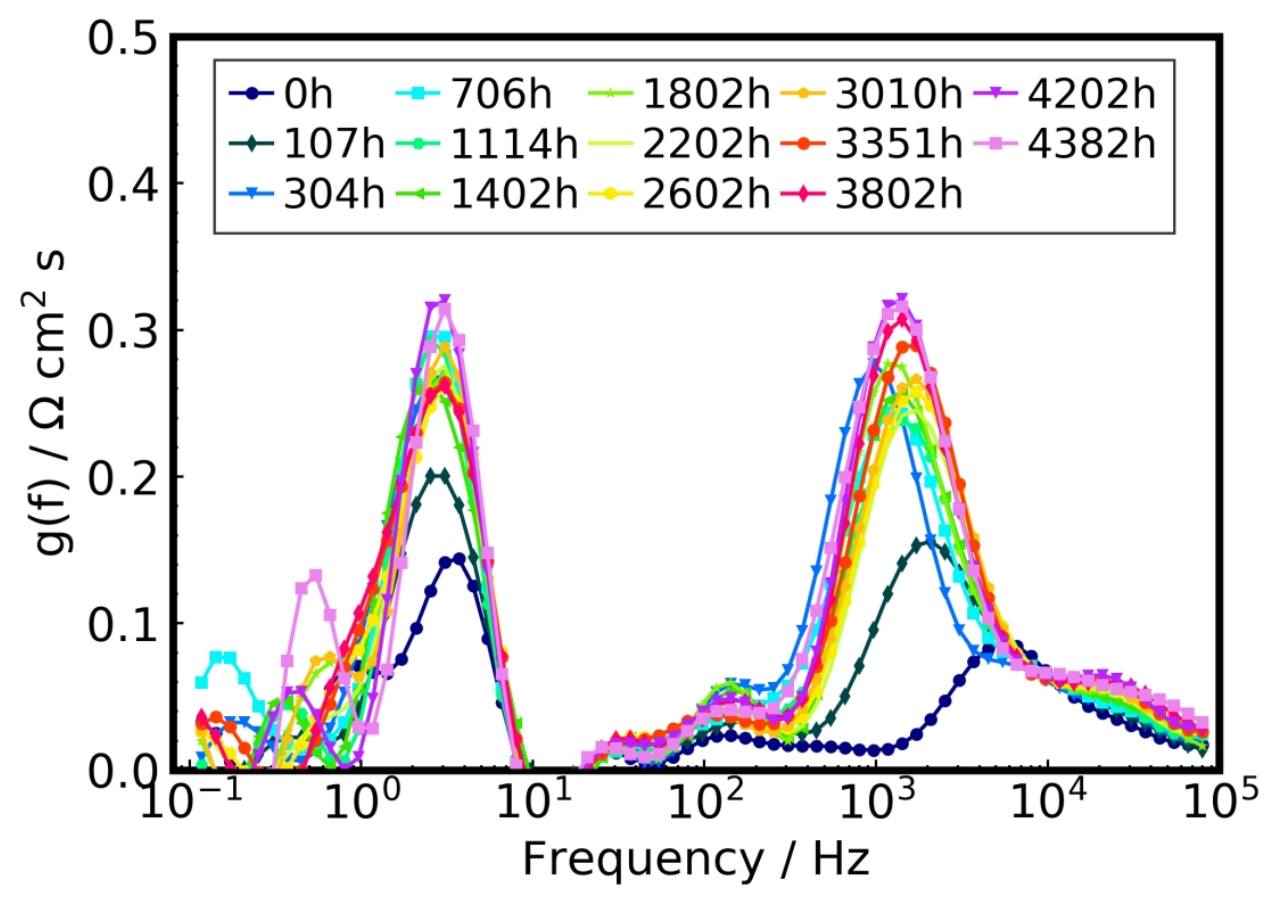

Figure 4: DRT analysis of the impedance spectra recorded during the durability test at $-1 \mathrm{~A} \mathrm{~cm}^{-2}$. $177 \times 127 \mathrm{~mm}(300 \times 300$ DPI $)$ 
Figure 5: Cell component/process resistances as a function of time based on break down of the impedance spectra measured during the durability test.

$177 \times 101 \mathrm{~mm}(300 \times 300 \mathrm{DPI})$ 

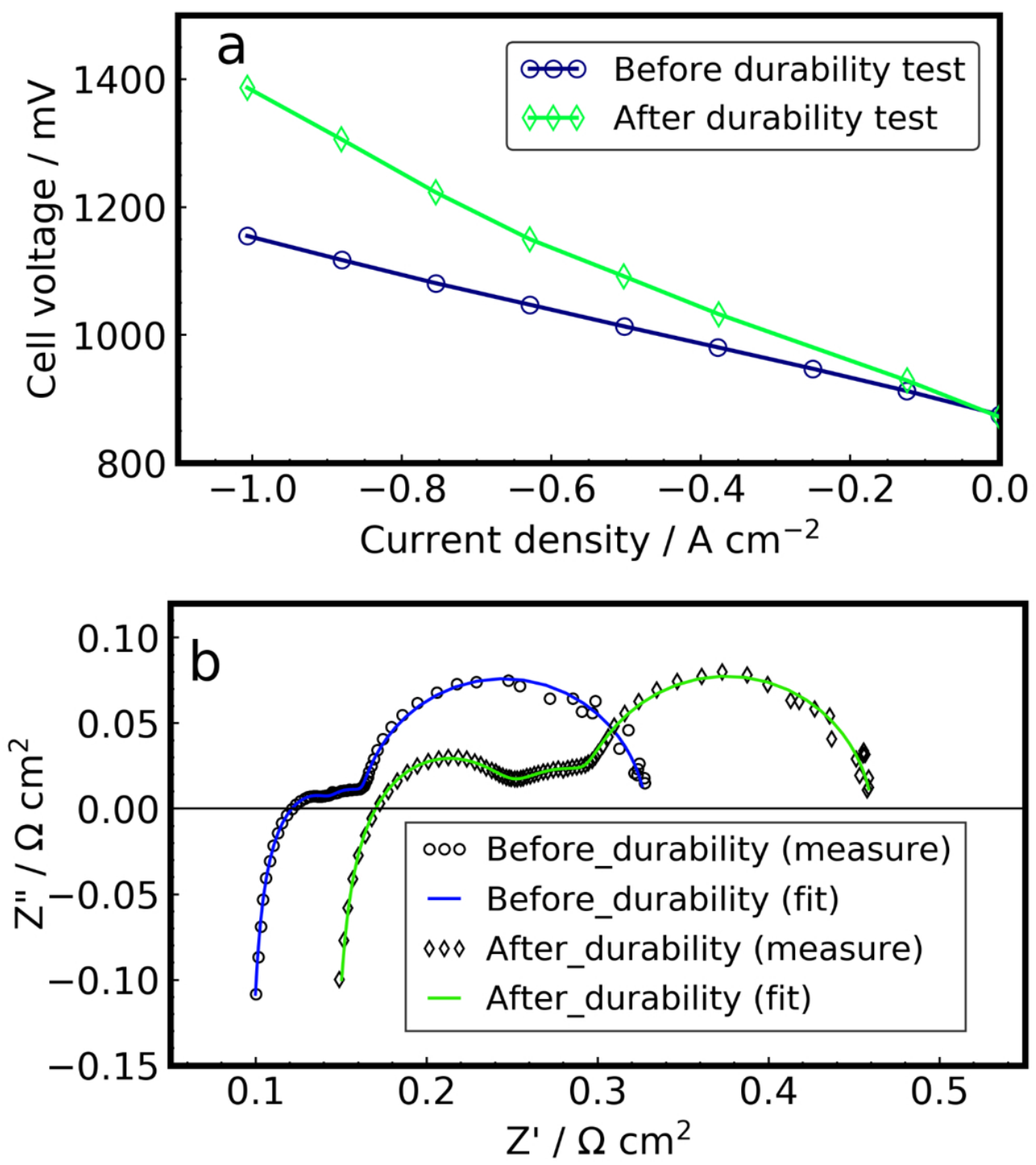

Figure 6: Cell performance characterizations before and after the durability test at $800{ }^{\circ} \mathrm{C}$ with $10 \% \mathrm{H}_{2}+$ $90 \% \mathrm{H}_{2} \mathrm{O}$ applied to the Ni-YSZ electrode and $\mathrm{O}_{2}$ applied to the LSCF-CGO electrode. a: iV curves, b: electrochemical impedance spectra measured under zero DC current.

$88 \times 100 \mathrm{~mm}(300 \times 300 \mathrm{DPI})$ 

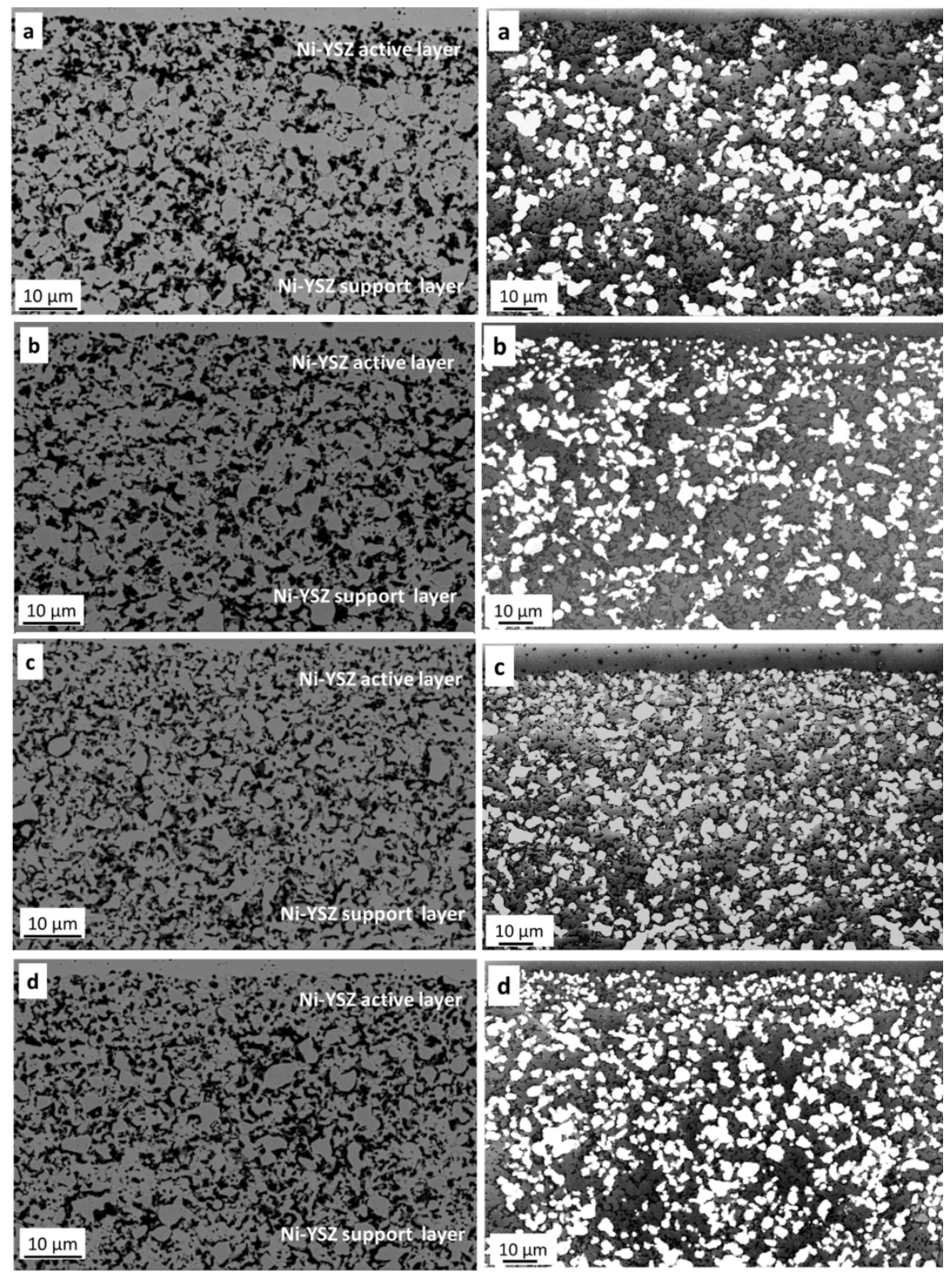

Figure 7: BSE (left) and LV (right) images of the Ni-YSZ hydrogen electrode at the hydrogen-steam inlet (a) and outlet (b) for the long-term tested cell and inlet (c) and outlet (d) for the reference cell.

$225 \times 304 \mathrm{~mm}(300 \times 300 \mathrm{DPI})$ 


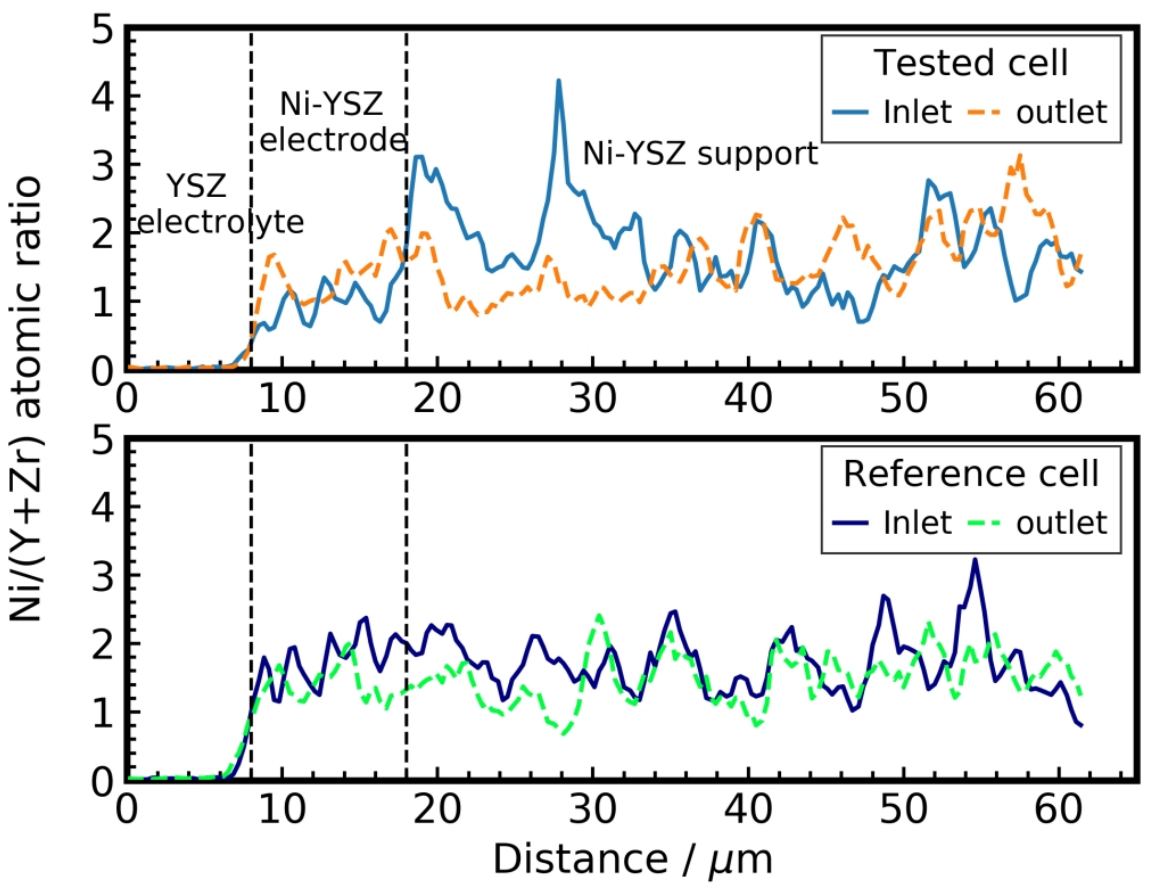

Figure 8: Atomic ratio of $\mathrm{Ni} /(\mathrm{Y}+\mathrm{Zr})$ for the active $\mathrm{Ni}$-YSZ hydrogen electrode and the support, derived from integrated EDS line scan perpendicular to the YSZ electrolyte - Ni-YSZ electrode interface.

$$
203 \times 152 \mathrm{~mm}(300 \times 300 \text { DPI) }
$$



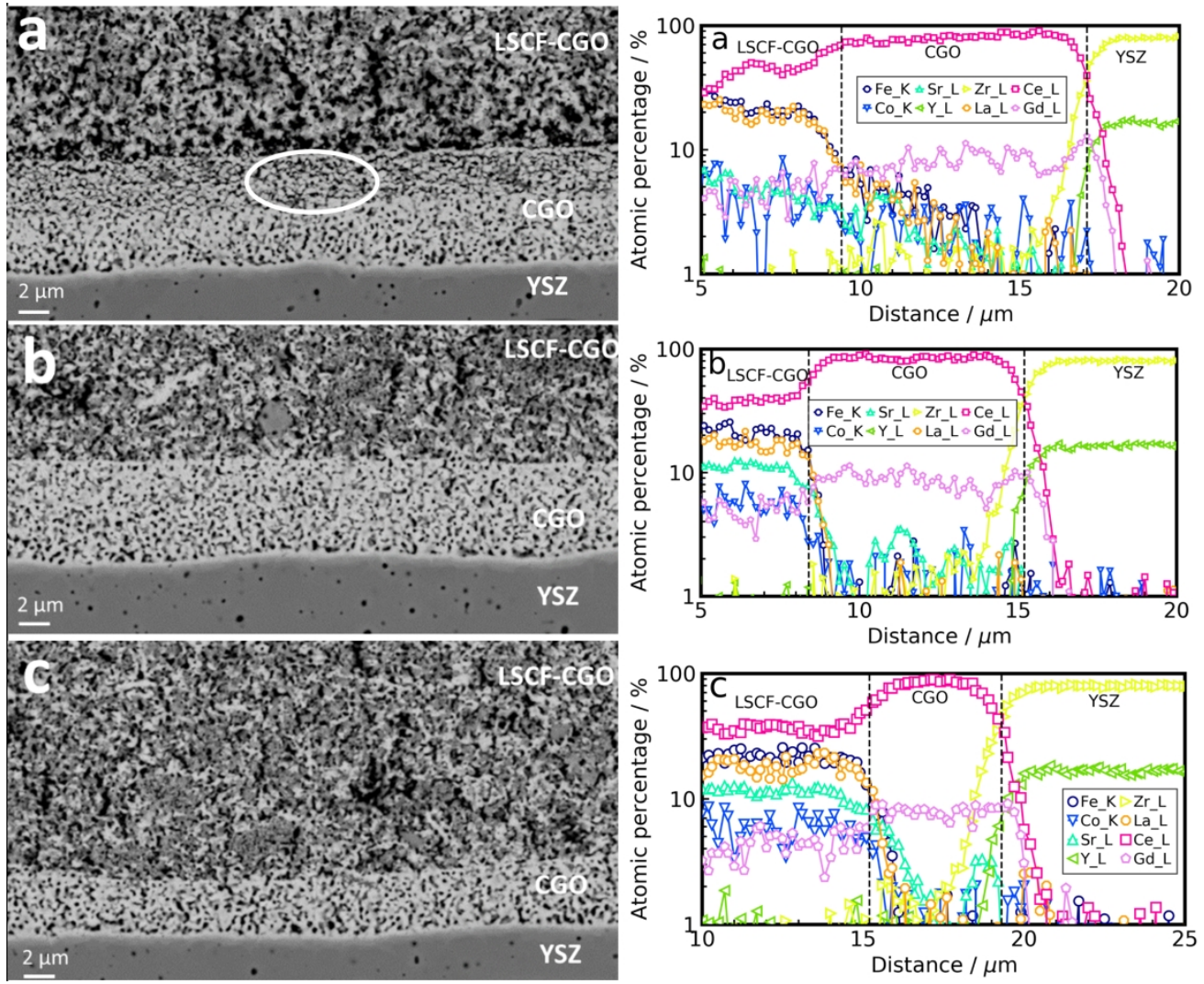

Figure 9: BSE images (left) and EDS line-scan (right) of the LSCF-CGO oxygen electrode, CGO barrier layer and YSZ electrolyte at the hydrogen-steam inlet (a) and center (b) of the tested cell and the inlet (c) of the reference cell.

$196 \times 160 \mathrm{~mm}(300 \times 300 \mathrm{DPI})$ 